\title{
SELPLG wt Allele
}

National Cancer Institute

\section{Source}

National Cancer Institute. SELPLG wt Allele. NCI Thesaurus. Code C128477.

Human SELPLG wild-type allele is located in the vicinity of 12 q24 and is approximately 12 $\mathrm{kb}$ in length. This allele, which encodes P-selectin glycoprotein ligand 1 protein, plays a role in the regulation of migration and cell adhesion for leukocytes. 